\title{
MODEL FOR CHARGING DEPRECIATION OF NON - FINANCIAL FIXED ASSETS BY BUDGET ORGANIZATIONS
}

\author{
D. Velikov* \\ Department of Finance and Management, Faculty of Economy and Social Sciences, \\ Plovdiv University "Paisii Hilendarski", Plovdiv, Bulgaria
}

\begin{abstract}
The aim of this article is to develop an accounting model to improve the collection, analysis, processing and presentation of depreciation information in the public sector by means of accounting methods and to assess the possibility of reporting under International Public Sector Accounting Standards (IPSAS). Depreciation is a process of gradually transferring the value of the tangible and intangible assets in the cost of the finished product. Obsolescence due to technological developments and physical wear is associated with elements of the machine, without which it cannot work. Not depreciated land, forests, monuments, fully depreciated assets and those who are in the process of acquisition. Depreciation in the public sector is allowed to Treasury 05 in 2016 to the Minister of Finance and covers all non-financial fixed assets of budget organizations. The methods used are analysis and synthesis and modeling. The results are depreciation accounting model. The conclusion is that the proposed model allows accounting for depreciation of the non-financial fixed assets in the budget sector and that the IPSAS application is not regulated in Bulgaria.
\end{abstract}

Key words: depreciation, non-financial fixed assets, public sector, accounting, standards

\section{INTRODUCTION}

Depreciation is a process of gradual transfer of the value of tangible and intangible fixed assets to the cost of the finished product, ie. reducing the cost of an asset due to wear or tear. The term has a Latin origin and means "killing". The depreciation is a real economic process that is inherent in any business activity in which tangible (and intangible) assets with long-term use are utilized, under the legal form of the enterprise, within which that activity is carried out [1]. The moral wastage is related to the development of technologies, and the physical wear is associated with machine's parts without which it cannot work. Depreciation is not accounted for land, forests, cultural monuments, fully depreciated assets and those that are in the process of being acquired. Public sector depreciation is authorized by the Minister of Finance with Treasure Directorate (Treasure) №05 dated 30.09.2016 "On the accrual of depreciation of non-financial fixed assets by

\footnotetext{
*Correspondence to: Diyan Velikov Velikov, Department of Finance and Management, Faculty of Economy and Social Sciences, Plovdiv University "Paisii Hilendarski", Plovdiv, Bulgaria, 24 Tsar Asen Str, Tel .: +359878 529847,e-mail: diyan.velikov@mail.bg
}

budgetary organizations" and covers all nonfinancial fixed assets (NFFAs) of budget organizations.

\section{General conditions}

The purpose of depreciation is to satisfy the concept of "true and fair presentation " of the entity's assets, grounded on the principle of materiality in the Accountancy Act [2]. It is assumed that the value of tangible fixed assets included in the group of depreciable assets is carried forward in parts by rescheduling their estimated useful life as an expense in the cost of the product produced in the enterprise by living human labor [3]. The Minister of Finance approve accounting standards and chart of accounts and give instructions to budgetary organizations [4]. According to item 4 of the Treasure No. 20 / 14.12.2004 on the application of the National Accounting Standards (NAS) by the budget enterprises, the orders of the NAS 4 Report of the depreciation (NAS 4) are not applied by the budget enterprises. In 2017, this problem is overcome on the basis of the instruction Treasure No5 on the charge of depreciation of NFFAs by budget organizations. The positions presented in the financial statements are recognized and measured in accordance with the principles described in Art. 26, para. 1 of the 
Accountancy Act. The principles of "caution", "accrual" and "comparability of revenue and expenditure" are observed. Depreciation allows valuation and accounting of the supposed risks and expected losses from the assets and liabilities held. The recognition of depreciation costs for the current reporting period ensures compliance with the accrual principle.The accrual of the cost of depreciation of assets and the income from their exploitation allows their comparison.

\section{Object of regulation}

NFFAs are Fixed Tangible Assets (FTAs) and Fixed Intangible Assets (FIAs). In Accounting Standards (AS) 4 "Accounting for depreciation" it is stated that a depreciable asset is a durable tangible or intangible asset that is expected to be used during more than one reporting period, it has a limited useful life and it is held by the entity for the purpose of production or supply goods and services, for rental to other persons or for administrative purposes [5]. The accrual of depreciation in the accounting systems of budgetary organizations is expected to improve the quality of accountability and public finance statistics as this will allow for substantial costs to be covered (such as depreciation costs), which in turn leads to a more correct measuring the cost of public services and activities. At present, the problem of the depreciation of NFFAs in public sector enterprises is up - to date, subject to discussion and it has public relevance. Evidence for this is the strong dependence of statistical information at European level on the quality of the accounting information base for public finances [6]. Depreciation costs as an accounting statement of the extent of use of NFFAs in the provision of public services and activities are treated as transactions and are included in operating expenses, while accounting devaluations (as well as revaluations) of non-financial assets reflects the effect of other events - losses (gains) on the holding of the asset and are not included in measuring the cost of public services and activities. From taxation point of view according to item 12.4 of Treasure No 20 / 2004 in the accounting systems of the budget organizations there are no temporary tax differences and no deferred tax assets and liabilities are recognized. The Corporate income tax law (CITL) will not be applied to the development and updating of tax depreciation plans and the calculation of depreciation expense for tax purposes.

\section{Definitions and scope of assets subject to depreciation}

For the purpose of applying Treasure No 05, the definitions set out in points 9 (a) to (m) of Treasure No 05 are used. They are an adapted version of the relevant definitions in AS 4. In the balance sheet of public sector enterprises, assets are structured into two main groups financial and non-financial assets. Nonfinancial assets include FTAs and FIAs and inventories. NFFAs are FTAs and FIAs, the accounts of which are listed in Section 2 of the Bill of accounts of budgetary organizations (BABO) - FTAs and FIAs accounts. The accounts are described in Group 20 FTAs, Group 21 FIAs and Group 22 Fixed assets, capitalized in the reporting group (business area) "Other accounts and activities". These are active, balance accounts. They are synthetic and analytical accounts can be associated with them. All NFFAs are subject to depreciation, except for those described in paragraph 23 (a) to (m) of Treasure No 05.

\section{Depreciation methods}

For the selection of a specific depreciation method for an asset, the guidelines of AS 4 are followed, except when specific requirements for the determination of depreciation methods for certain assets are specified with the Ministry of Finance's instructions. Under the linear method, depreciation is allocated in proportion to the periods that cover the estimated useful life of the depreciable asset.. For the non-linear methods, depreciation rates differ for different periods of the estimated useful life of depreciable assets. They can be:

(A) decreasing non-linear depreciation - the decreasing residue method, the even decrease method, the decreasing sum of the numbers and the uneven decrease method;

(B) increasing non-linear depreciation methods - the method of the even increase, the method of the increasing sum of the numbers and the method of the uneven increase.

The choice of depreciation method should, in principle, reflect the pattern of consumption of the economic benefits and potential contained in the depreciable asset [7]. The depreciation method reflects the pattern in which the future economic benefits associated with the asset are expected to be consumed by the entity. The depreciation method applied to each FTAs in public sector entities should be tested for adequacy at least once a year at the end of the financial year.

\section{Depreciation costs}

Depreciation costs in the budget enterprise can be qualified according to certain criteria. Depending on their origin and economic content, depreciation costs (DCs) are material. 
According to their functional purpose, DCs cover the various activities - basic, auxiliary, administrative, sales, and other - for which they are performed. Depending on the nature and type of business operations, DCs are nonfinancial costs. According to their relationship with the value of the newly created product, DCs are direct costs. Depending on the volume of economic activity, DCs are permanent / conditional - permanent /. Depending on their role and purpose, DCs are basic costs. In relation to the Statement of income and expense (Income statement) and the relevant presentation of DCs, the last are shown as operating expenses (costs by economic elements). The recognition of DCs in the budget enterprise is made by inclusion in the financial statements if there is an asset decrease or an increase in a liability and these changes can be measured reliably.

\section{Depreciation model}

The BABO provides two types of accounts to cover both sides of the amortization process accounts for reporting (flow) flows from subgroup 603 of BABO and Balance Sheet Accounts (Corrective) from group 24 of $\mathrm{BABO}$. According to the degree of aggregation of the accounting data, synthetic accounts are used. According to their relationship with the balance sheet they are active - account 603 and passive - accounts 241 and 242. Considering the economic nature of the objects reported in them, these are accounts for the reporting of the state and the change of NFFAs. According to their structure and functional purpose, regulatory, corrective account of group 24 of BABO is used for accounting for depreciation in budget organizations. They are also called opposites, decreasing and counter. The Group 24 accounts structure unambiguously corresponds to the balance sheet items for the relevant NFFAs allowing the Group 24 account data to be automatically reported in the balance sheet as a correction for the relevant balance sheet item without additional identification at the analytical level. Since only one item is included in the profit and loss account for depreciation costs, the balances of all accounts in subgroup 603 (before the closing operations) will be taken into account. Subgroup 603 accounts are closed to the end of the year with account 1201 Change in Net Assets for the Period. Account 1201 is closed in all three reporting groups (business areas) with account 1101 Accumulated Change in Net Assets. With a view to the application of Treasure No 5 for 2017 "... without being a calculation element, even if it is necessary, the depreciation remains the immediate burden of the reported result for the period - it represents a reduction of the net profit (respectively the increase of the net loss) [8]. In view of the intended purpose and the manner of formation of the depreciation charges, we consider that it is appropriate to form an "Depreciation Fund" in Group 603 of BABO. In this respect, the experience of the Bulgarian National Bank according to which the "Depreciation Fund" is a monetary expression of BNB funds intended for restoration and major overhaul of the main funds is interesting [9]. The accounting for the depreciation of budget organizations is as follows:

1. for depreciation of FTAs of group 20 of BABO:

Dt 6032 - 6036, 6039 / Kt 2412 - 2416, 2419

2. for depreciation of FIAs group 21 of BABO: Dt 6030 / Kt 2420

3. for depreciation of FTAs of group 22 of BABO (only for assets accounted for in 2202): Dt 6037 / Kt 2417

The analytical accounting of the depreciation means should be organized on the accounts from group 60 of the BABO by two analytical accounts - "Amortization for recovery" and "Depreciation for overhaul". The former are accrued for the purpose of capital investments and the latter for major overhaul of the main funds. The use of a "fund" principle in accounting for depreciation in budget entities will allow the target to be met for their accumulation and use. Differentiated reporting in three reporting groups (business areas) also applies to the depreciation charge, ie. the depreciation expense is charged to the reporting group (business area) where the asset is positioned at the date of commencement of the depreciation charge. There is not accrual depreciation in the reporting group (business area) "Accounts for EU funds" (AEUF). In the AEUF, the reporting of NFFAs is limited to the processes of acquisition, temporary storage and allocation / transfer. Their permanent recording and accrual of depreciation are reflected only in reporting groups "BUDGET" and "Other accounts and activities" (OAA). The strike off of the NFFAs is accomplished at balance value and the corresponding entry is as follows:

Dt account from group (A/G) 24 Accumulated Depreciation (AD) /

Dt accounts 613, 614, 64, 6992, 76X2 - ball. value $(\mathrm{AV}-\mathrm{AD}) /$

/ Кт (A/G) 20, 21 and 22 - Account. Value $(\mathrm{AV})$,

In the case of the sale of the reporing in "OAA" depreciated NFFAs from Group 22 (in practice these are only infrastructure items 
accounted in account 2202) and account 2099, it should be reflected in the "BUDGET", including the balance value (BV) of the sold depreciable assets transferred from the "OAA" to the "BUDGET" through account 7602. RECORDING IN "BUDGET":

1. Dt (A/G) 41, 48, 50 et seq. / Kt 7132 and 7149

2. Dt 6132 and 6149 balance value (BV) / Kt 7602

RECORDING IN "OAA": 1. NO RECORDING

2. Dt 2417, 2419, 7602 - at BV / Kt 2202 and 2099

The revaluation and devaluation of depreciable NFFAs are applied to the balance value and the respective records do not affect the accounts of Group 24 of BABO and the increases / decreases in the balance value are reflected only in the accounts of groups 20,21 and 22 of BABO, as determined by the standards and instructions under Art. 164, para. 1 and 3 of the PFA. When transferring depreciable assets between budget organizations within the system of the First Level Manager with Budget (FLMB), the recipient can take the asset under one of the two approaches:

(A) gross coverage of Account Value (AV) Accumulated Depreciation (AD) (Recommended Approach):

Dt (A/G) 20, 21 and 22 - at AV/

$$
\text { /Kt 4500, } 7600 \text {-at AV-AD) }
$$$$
\text { / Kt (A/G) } 24 \text { - at AD }
$$

(B) direct recording at net (balance value): Dt (A/G) 20, 21 and 22 at BV / Kt 4500, 7600 at BV

In the case of gratuitous transfer of depreciable assets in the system of different FLMB, the records are:

Recorded in the RECEIVER:

Dt (A/G) 20, 21 and 22 at B / Kt 76X2 at BV Recording in the TRANSFERER:

Dt 2417, 2419 /

Dt 76X2 - at BV / Kt (A/G) 20, 21 and 22

Depreciation policy, change in accounting policy and estimates related to depreciation of NFFAs

The directions of paragraphs 7.1-7.3 of AS 4 are generally applied by budget organizations. The FLMB should ensure that, as far as possible, uniformity and consistency is achieved in the core issues of depreciation policy within its entire system of Lower Level Manager with Budget. The change in depreciation parameters has reflected as a change in the accounting estimates, ie. is reflected in the current and future reporting periods without the need for change for the past reporting periods. The change in the accounting policy in terms of depreciation does not apply with rebound to past years, the comparative information for previous periods is not recalculated and pro forma reports are not prepared. In the case of changes in the accounting policy that have a significant impact on previous years' data at the consolidated reporting level in the FLMB system and there is a practical possibility to measure this effect with reasonable accuracy, its nature and amount are announced in the annual financial statements .

\section{Determination of the expiration date of depreciable assets}

The determination of the useful life of the depreciable assets is made by the budget organization following the guidelines of item 3 of the AS 4, except where the minimum or maximum deadlines for certain assets are set with the Ministry of Finance's instructions. The expiration date obtained from the provisions of Art. 55 of the CITL tax depreciation norms should in principle not be taken into account as they are defined only for the purpose of the have to be taken into account. Depreciation of depreciable assets deposited by the government / municipalities to the budget organization, recorded on the balance sheet of the budgetary receiving organization, shall be charged in it. Capitalized expenses for overhaul and reconstruction of behind balance-sheet depreciable assets allocated for use for a certain period are depreciated for the shorter than expected economic useful life of the capitalized costs and the residual term of the rental / use of the asset. For the depreciable assets acquired through finance leases the expiration date shall be determined in accordance with point 35 of Treasure No 05 .

\section{Launching and terminating the depreciation charge}

As far as the quarterly distribution of the annual depreciation quota is adopted in the system of FLMB, the start-up and termination of depreciation starts from the beginning of the quarter following the quarter in which the ground for the commencement (renewal) or termination of the depreciation charge has occurred. For practical reasons, it is permissible for all depreciable assets acquired / put into use during the last quarter of the financial year or for individual classes of these to adopt an accrual basis for the depreciation of such assets from the January of the following year.

\section{Depreciation plan (DP)}

Budget organizations develop and validate an DP for each depreciable asset in accordance 
with paragraphs 8.1 to 8.3 of AS 4. For different computer configurations, groups of homogeneous types and the same amount of depreciable assets and other asset configurations, a DP may be developed. If an asset includes separate identifiable and replaceable components with a lifetime different from that of the whole asset, it is permissible to develop a separate DP for that component as far as to the depreciable value of the entire asset may be allocated on a reasonable basis between that component and the rest of the asset. For infrastructure projects such as roads, bridges and other similar infrastructure, a depreciation approach may be adopted by developing a separate DP of the realized and capitalized overhaul costs for the respective year of the respective distinct asset. Applying the capabilities of an individual DP does not lead to a change in the method of synthetic and analytical reporting of the asset [10]. Considering that the accounting framework for budgetary organizations does not provide for direct revaluation gains and losses in the available capital, the reserve of ex-post evaluations is not applicable to the budgetary organizations. The DP should be updated in case of recalculation, revaluations and other similar correction to the balance value (BV) that affects the post - depreciation process. The requirement to produce a summary DP under item 8.3 of AS 4 may be applied at the level of a synthetic accounting or sub - account statement, ie. instead of a summary DP, generalized DPs for depreciable assets reported on a synthetic account / subaccount are developed [11].

\section{Announce \\ In the annual financial statements, an entity should announce the depreciation methods adopted for the separate asset groups and a justification for a change in depreciation methods, if any [12]. The information is announced in the annual financial statements when depreciation costs for the current or previous year are significant.}

\section{Transitional period}

In accordance with the requirements of Art. 67, para. 1 of a Ministerial council decree No. $380 / 2015$, the transition to accrual of depreciation should be made by the end of the reporting and the reporting period for 2017. When depreciation is charged in the annual financial statement for 2017, the amounts for depreciation relating to the whole period of the financial year should be included starting from 01.01.2017 or the date of acquisition / entry of the asset (if later than 01.01.2017) by 31.12.2017 or the date of removal of the asset (if earlier than 31.12.2017). At the initial start of the depreciation charge on the depreciable assets available in the DP, the balance value can be directly billed. Two approaches are applied - gross value approach - the DP includes both the balance value of the asset before the depreciation for 2017 and the accumulated depreciation of the asset for 2017 and net value approach - the asset value of the asset formed after the calculation of depreciation is entered in the DP. When applying the net value approach to netting, one of the following records is made:

Dt (A/G) 24 / Kt (A/G) 20, 21 and 22 ("black") or Dt (A/G) 20, 21 and 22 / Kt (A/G) 24 ("red")

\section{A model for accruing depreciation of tangible fixed assets in public sector enterprises in accordance with International Public Sector Accounting Standards (IPSAS)}

IPSAS is currently the only internationally recognized composition of accounting standards for the public sector. They are based on International Financial Reporting Standards (IFRS), which are widely applied in the private sector and currently contain a composition of 32 accrual accounting standards and one cash basis standard. Opportunities to improve reporting by applying accrual accounting methods are included within the IPSAS framework. Their application depends on the adoption of the IPSAS. The International Monetary Fund (IMF) currently requires the use of the new government finance statistics (IMF Manual of Government Finance Statistics, 2001, GFSM 2001) which is designed to reflect public sector operations on an accrual basis in order to harmonize government finance statistics with other macroeconomic statistics. Leading in defining the GFSM 2001 framework is the System of National Accounts (1993 SNA 1993) [13]. In IPSAS 17 Property, plant and equipment is stated that an enterprise should determine depreciation for each significant portion of the item property, plant and equipment. The Standard requires the creation of balance sheet accounting information for the accrual of depreciation of FTAs. To the extent that an entity depreciates separately certain parts of an item of property, plant and equipment, it also depreciates separately the remainder of the asset. According to IPSAS 17 a key point in the research model for the depreciation of fixed assets in public sector enterprises is the determination of the useful life of their use. The residual value and useful life of the asset must be revalued at least once annually by the 
end of the reporting period and if there are significant differences from previous estimates, changes should be accounted for as a change in accounting estimates in accordance with IPSAS 3 Accounting policies, changes in accounting estimates and errors. Depreciation expense for the period should normally be recognized as an increase or decrease in net assets for the period. Sometimes future economic benefits associated with an asset are absorbed in the production of other assets. In this case, the depreciation expense is part of the cost of the other asset and is included in its balance value (BV). For example, the depreciation of production machinery and equipment is included in the cost of transforming inventories, as is the approach used in IPSAS 12 Inventories. Similarly, the depreciation of property, plant and equipment used for development activities may be included in the cost of an intangible asset recognized in accordance with IPSAS 31 Intangible Assets [14]. The adoption of this model will enable the financial statements of public sector entities to announce, for each class of property, plant and equipment, the full accounting information on depreciation in the budget sector on an accrual basis.

\section{CONCLUSION}

The accrual of depreciation of NFFAs in budget entities and their accumulation as a change in net assets for the period and then as an accumulated change in net assets may result in accounting for financial losses for the period. These financial losses can lead to decapitalization of budget enterprises, which increases the risk of their functioning. The use of a "fund" principle in accounting for depreciation in budget entities will allow the target to be met for their accumulation and use. The accrual basis of reporting enables the state to better assess the value of its assets and liabilities and the net wealth as well as its impact on the sustained fiscal policy. The proposed model allows accounting for depreciation of the NFFAs in the budget sector and conclude that the IPSAS application is not regulated in Bulgaria. Reporting by applying accrual accounting basis included in the IPSAS shall harmonize government finance statistics in Bulgaria with other macroeconomic statistics.

\footnotetext{
ABBREVIATIONS

IPSAS- International Public Sector Accounting Standards;

Treasury - Treasury Directorate of the Ministry of Finance; NFFAs - Non-financial fixed assets; FTAs - Fixed Tangible Assets;
}

FIAs - Fixed Intangible Assets;

BABO - Bill of Accounts of the Budgetary Organizations;

DCs - depreciation costs;

DP - Depreciation plan;

AEUF - Accounts for EU funds;

OAA - Other accounts and activities;

BV - Balance value;

AV - Account Value;

$\mathrm{AD}$ - Accumulated Depreciation;

A/G - account from group;

1201 - Change in Net Assets for the Period;

1101 - Accumulated Change in Net Assets;

Group 20 of BABO - tangible fixed assets; Group 21 of BABO - Intangible Fixed Assets; Group 22 of BABO - Fixed assets capitalized in the reporting group (business area) "Other accounts and activities";

2202 - Infrastructure Objects;

Group 24 of BABO - Depreciation of Fixed Assets;

241 - Depreciation of tangible fixed assets;

242 - Depreciation of intangible fixed assets;

41 - Clients;

48 - Other estimates;

50 - Cash;

Subgroup 603 of BABO - Depreciation costs; 6132 - Book value of sold infrastructure;

6149 - Book value of other tangible fixed assets sold;

7132 - Revenue from sales of infrastructure;

7149 - Revenues from sales of other fixed assets;

7602 - Internal non-cash transfers between "BUDGET" reporting groups and "Other accounts and activities".

\section{REFERENCES}

1. Hristina G. Oreshkova, Scientific and theoretical - methodological problems of management of the depreciation process in the enterprise, Dissertation, University of National and World Economy, 2006, Sofia, p. 28.

2. Law on Accounting, Art. 26, para. 1, item 6.

3. Dushanov, Ivan, M. Dimitrov, Business Accounting Course, Trakia M, C., 2016, p. 131

4. Public Finance Act, Art. 164, para. 1, items $1-4$.

5. Accounting Standard 4 - Accounting for Depreciation, item 2.

6. Feschiyan, Daniela, Determining the Depreciation of Non-Financial Fixed Assets in Public Sector Enterprises, Institute of Certified Public Accountants Magazine, 2016, p. 4, pp. 1 - 17.

7. Treasure Directorate of Ministry of Finance 05 from 30.09.2016, No. 05, items 42 - 43. 
8. Hristina G. Oreshkova, op. sit., P. 113.

9. Pavlov, V., K. Pergelov, G. Naumov, Accounting of BNB and DSK, DI, Varna, 1965, p. 166.

10.Treasure Directorate of Ministry of Finance 05 from 30.09.2016 No. 05, item 48 - 52.

11.Treasure Directorate of Ministry of Finance 05 from 30.09.2016 No 05, items 53 - 54.
VELIKOV D.

12.Accounting Standard 4: Accounting for depreciation 4, item 9.

13. See Methodological Frameworks of the IMF Manual for Government Finance Statistics 2001, (GFSM 2001).

14. Handbook of International Public Sector Accounting Pronouncements, 2016, IFA, Volume 1, p. 584. 